\title{
【論【文】
}

\section{SLCAを用いた容器類の収集・再資源化 システムの違いが環境に与える影響の評価}

\author{
中 野 加都子* ・ 三 浦 浩 之* - 和 田 安 彦*
}

\begin{abstract}
【要 旨】容器包装リサイクル法の施行に向けて, リサイクルに関わる環境への影響を低減化していく ためには，収集・再資源化システムを機能単位としてとらえた SLCA (Service Life Cycle Assessment）を実施する必要がある。

これは，現在最も一般的に行われている製品を対象としたPLCA (Products Life Cycle Assessment）とは別の切り口からのアプローチである。本論文は，ある都市で実際に行われている容器類の 収集・再資源化システムに SLCA を適用し，都市規模の似た別の都市で行われている収集・再資源化 方式を採用した場合との環境への影響を比較することにより，環境負荷の少ないリサイクルシステムを 検討するためのケーススタディを行ったものである。その結果, 収集・再資源化方式を变更することに よる環境への影響の違いと,リサイクルを行ううえで「収集」が強い影響をおよばすことを明らかにし た。

キーワード：収集・再資源化システム，リサイクル，SLCA，インパクト評価, 容器
\end{abstract}

\section{1. 序論}

平成 9 年の「容器包装リサイクル法」の施行に伴い, 本格的なリサイクル時代を迎えたわが国では, リサイク ルを円滑に行うための収集・再資源化システムの早急な 整備が必要である。また，全国的にリサイクルが実施さ れた場合にはリサイクルに伴う環境負荷がかなり増大す ることが予想されるため, 現状における収集・再資源化 システム上, 環境負荷增大の原因となるプロセスを明確 にし, それに基づいてリサイクルのための収集・再資源 化システムをできるだけ環境負荷低減化型に改善してい く必要がある。

著者らはこれまでの論文卢)で, LCA (Life Cycle Assessment）手法を用いてリサイクル効果を定量化する 方法を提案し、リサイクルによる環境負荷低減化効果を 評価する場合には, リサイクルによって再生材料を製造

原稿受付 1996.5.27

* 関西大学工学部環境工学研究室

連絡先：干 564 吹田市山手町 3-3-35 関西大学工学部環境工学研究室 和田 安彦
する場合の環境負荷と、ごみとして処理処分した場合の 環境負荷に再生材料之同量の材料を新たな資源から製造 する場合の環境負荷を加えて比較する必要があることを 述べてきた。また，わが国の現状のリサイクルシステム では輸送距離，減容化の有無がリサイクルする場合の環 境負荷に大きな影響を与える可能性が高いことを指摘し， 輸送や減容化が環境負荷におよぼす影響も含めて評価す る必要があることを述べてきた。

このようなこれまでの検討から，今後特に自治体等で 収集を行う容器類等の輸送に関する諸条件, 減容化の有 無が環境に与える影響等に焦点をあてて LCA を実施す る場合は，廃棄されてから以降の収集・再資源化システ ムの違いによる環境への影響を分析・評価する方が効果 的な結果を得ることができると考えられる。これには, 現在最も一般的に行われている「製品間の環境負荷の比 較」「環境負荷低減面からの製品・製法等の改善点の抽 出」等を目的とし, 製品機能およびシステムの範囲を設 定して製品の一生における環境負荷を皘算し, 環境への 影響を評価する PLCA (Products Life Cycle Assessment）とは別の切りロからのアプローチが必要で ある。 
すなわち, ある一定の種類, 量の容器を収集してから 再資源化を行うまでの機能単位を定義し，可能と考えら れるいくつかの収集・再資源化システムを設定して，そ の中から最も環境への影響の少ないあのを選択していく 必要がある。このような収集・再資源化システムを対象 とした LCA は，一般の製品を対象として行われる PLCA ではなく，収集・再資源化というサービスを対 象として LCA 評価を行うあのであるため, SLCA（Service Life Cycle Assessment) の一つと考えられる。

本論文ではある都市における収集・再資源化システム を変更した場合の環境への影響を，現行と比較する SLCA のケーススタディを実施し，リサイクルにかか わる環境への影響の低減化を図るための具体策を検討す る。

\section{2. 収集・再資源化システムが環境に与える影 電評価の考え方}

一般的に行われている「製品間の環境負荷の比較」を 目的として行われる PLCA では，同一効用を実現する $2 つ$ ついはそれ以上の製品が対象として選ばれ，同一 容量の飲料の提供, 標準的な家庭における洗剤の使用量 など，同等の機能単位が設定される ${ }^{6}$ 。

このような PLCA では対象製品を主体としたシステ ムのインプット, アゥトプットから環境への負荷が計算 されるため, 対象製品が他の製品にリサイクルされる場 合, リサイクルプロセスが環境におよぼす影響は対象製 品か再生品に割り振らなければならない》。

たとえば，Fig. 1 を用いてリサイクルプロセスの環 境影響の割り振りを示すと，
(1) 原製品 $\mathrm{A}$ ：再生品 $\mathrm{B}=50 ： 50$ で割り振る。

(2) すべての影響を製品 $\mathrm{A}$ に割り振る（廃棄物処理 工程と考える)。

(3) すべての影響を製品 B に割り振る（二次材料の 生産工程と考える)。

(4) 経済的価值に応じて影響を割り振る。 等の考え方がある。いずれにしてあリサイクルプロセス が環境におよぼす影響は，あるシナリ才設定に基づいた 一定のリサイクル方法（輸送距離, 手段, 減容化率, リ サイクル率等を固定）による環境負荷を製品 A, B のど ちらか，あるいは双方が負うことによって評価が行われ る。そのため,このような一般的な PLCA の方法によ れば評価結果はシナリオに直接依存してしまうことにな る゙。またたリサイクルに関連する一次製品システムと 二次製品システムとの間で様々な輸送距離, 手段, 収集 回数等を設定してリンクされた 2 つの製品システムの全 体を対象に環境への影響の評価を行おうとすると, シス テムが非常に複雑になり，実用的でない早。

容器包装リサイクル法の施行にともなって最も問題と なる、リサイクルに伴う環境負荷をできるだけ低減化す ることを目的として評価を行う場合，たとえば，収集頻
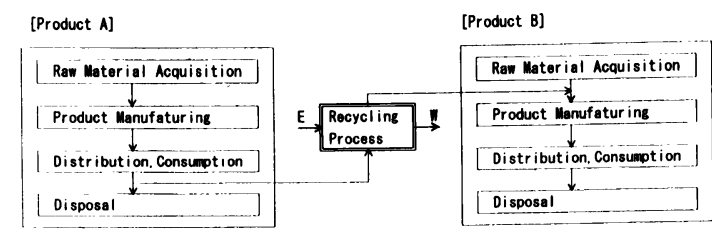

E. Input Energy

Fig. 1 System flow of recycling process

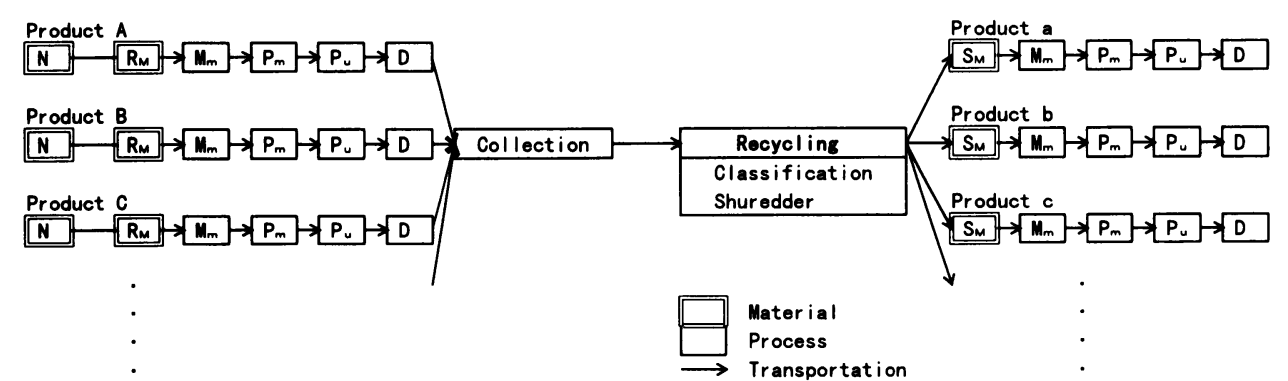

Primary Product System
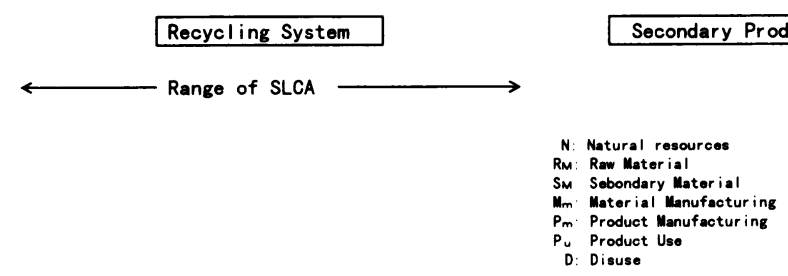

Fig. 2 Range of SLCA for recycling 
度 (回数), 分別方法, 輸送ルート, 減容化方法を環境 負荷低減化のためによ゙のように改善すべきかに焦点をあ てることが重要である。このような場合は評価対象製品 の 1 次製品システムの原料製造から廃棄（製品が不用と なって捨てた段階：disuse）まで，2次製品システムの 材料製造から廃棄までのプロセスは共通と設定すべきで あるため，この部分は省略することができ，収集・再資 源化というサービスを対象として，LCA を行う必要が ある。

このような SLCA の範囲は Fig. 2 のように設定する ことができる。この範囲において可能な様々な収集・再 資源化システムを想定して, 複数の環境負荷項目につい て一般的に行われている PLCA と同様の方法でインべ ントリ分析，インパクト評価を行いここれらの一連の分 析・評価によって最も環境への影響の少ない収集・再資 源化システムを選択し, 同時にそのシステムの中で最す 環境負荷の高いプロセスを特定することによって環境へ の影響の低減化策を具体化する必要がある。

\section{3. 収集・再資源化システムの変更によるイン パクト評価のケーススタディ}

本ケーススタディでは代表的な容器であるスチール年, アルミ缶, ビンの収集・再資源化システムとして, 都市 規模のよく似た S市, T市におけるシステムを取り上 げる。

そして，S市における現状の収集・再資源化システム である S市方式を， T市で行われている $\mathrm{T}$ 市方式に変 更した場合の環境への影響の評価をSLCA の手法を用 いて行い，収集・再資源化システムの変更を行った場合 の環境への影響の低減化の可能性について検討を行う。

\section{1 容器類の収集・再資源化システム}

\subsection{1 収集・再資源化方式}

$\mathrm{S}$ 市方式および $\mathrm{T}$ 市方式の収集・再資源化方式は以 下のとおりである。

・S市方式 $=2$ 種（スチール缶， アルミ缶)混合収集

$\rightarrow$ 再資源化 $+$ 1種(ビン)個別収集 $\rightarrow$ 再資源化

・T市方式 $=3$ 種（スチール年, アルミ缶, ビン)混合収集 $\rightarrow$ 再資源化

また, 各容器の諸元は Table 1 のとおりである。 3.1 .2 都市の規模
S 市の都市規模は Table 2 に示すとおりである。

\section{1 .3 収集車}

収集車両は両都市においてほとんどの場合が $2 \mathrm{t}$ パッ カ一車で行われていることから，ビンのみを単独で収集 する場合のみ $4 \mathrm{t}$ トラック（S市の実態から）とし，そ れ以外はすべて $2 \mathrm{t}$ パッカー車で行われているものとす る。

$2 \mathrm{t}$ パッカー車の燃費は $8.0 \mathrm{~km} / \ell$ （積載容量 : 4.0 $\left.\mathrm{m}^{3}\right), 4 \mathrm{t}$ トラックは $5.0 \mathrm{~km} / \ell\left(8.0 \mathrm{~m}^{3}\right)$ である。

収集車への積載量はそれぞれのパッカー車の最大積載 量をすとにし，収集する際に複数の容器を混載する場合 は, 車両に積載可能量分だけ容器の排出量の割合で積載 されるあのとした。これによって得られた各方式におけ る積載量を Table 3 に示す。

3.1 .4 収集方法と容器排出量

各方式による収集方法は Table 4 に示すとおりであ る。

また, 容器の 1 日あたり排出量は Table 5 のとおり

Table 1 Standard size of vessels

\begin{tabular}{|l|c|c|c|}
\hline & $\begin{array}{c}\text { Weight/ 1 vessel } \\
(\mathrm{g})\end{array}$ & $\begin{array}{c}\text { Volume/ 1 vessel } \\
(\mathrm{m} \ell)\end{array}$ & $\begin{array}{c}\text { Apparent volume/ } \\
\text { 1 vessel }(\mathrm{m} \ell)\end{array}$ \\
\hline Steel can & 50.0 & 350 & 525 \\
\hline Aluminum can & 17.8 & 350 & 525 \\
\hline Glass bottle & 300.0 & 300 & 450 \\
\hline
\end{tabular}

Apparent volume : volume $\times 150 \%$

Table 2 Scale of the S-city

\begin{tabular}{|l|l|}
\hline Population & 90,000 \\
\hline The number of household & 30,000 \\
\hline Area & $220 \mathrm{~km}^{2}$ \\
\hline Population density & 409.09 populations $/ \mathrm{km}^{2}$ \\
\hline Relative density of household & 136.36 houses $/ \mathrm{km}^{2}$ \\
\hline
\end{tabular}

Table 3 Number of vessels loading in a refuse collection vehicle

\begin{tabular}{|l|l|l|l|r|}
\hline & \multicolumn{2}{|c|}{ System in S-City } & \multicolumn{2}{c|}{ System in T-City } \\
\hline \multirow{3}{*}{ Vehicle 1 } & Steel Can & 4,571 & Steel Can & 4,076 \\
\cline { 2 - 5 } & Aluminum Can & 3,048 & Aluminum Can & 2,717 \\
\cline { 2 - 5 } & & & Glass bottle & 679 \\
\hline Vehicle 2 & Glass bottle & $\mathbf{8 , 8 8 9}$ & & \\
\hline
\end{tabular}

Table 4 Condition of each collection system

\begin{tabular}{|l|r|r|r|}
\hline & \multicolumn{2}{|c|}{ System in S-City } & $\begin{array}{c}\text { System in } \\
\text { T-City }\end{array}$ \\
\hline Vessel & Can & Glass bottle & $\begin{array}{c}\text { Can and } \\
\text { glass bottle }\end{array}$ \\
\hline Number of the stations & 1,000 & 1,000 & 1,000 \\
\hline Collecting distance & $57 \mathrm{~km}$ & $57 \mathrm{~km}$ & $57 \mathrm{~km}$ \\
\hline Transporting distance & & $57 \mathrm{~km}$ & \\
\hline Collection frequency & 2 times/month & 1 time/month & 2 times/month \\
\hline
\end{tabular}


Table 5 Average number of the reused vessels in S-city

\begin{tabular}{|l|c|}
\hline Vessel & $\begin{array}{c}\text { Average number of the reused vessels } \\
(/ \text { day })\end{array}$ \\
\hline Steel can & 12,329 \\
\hline Aluminum can & 8,219 \\
\hline Glass bottle & 2,055 \\
\hline
\end{tabular}
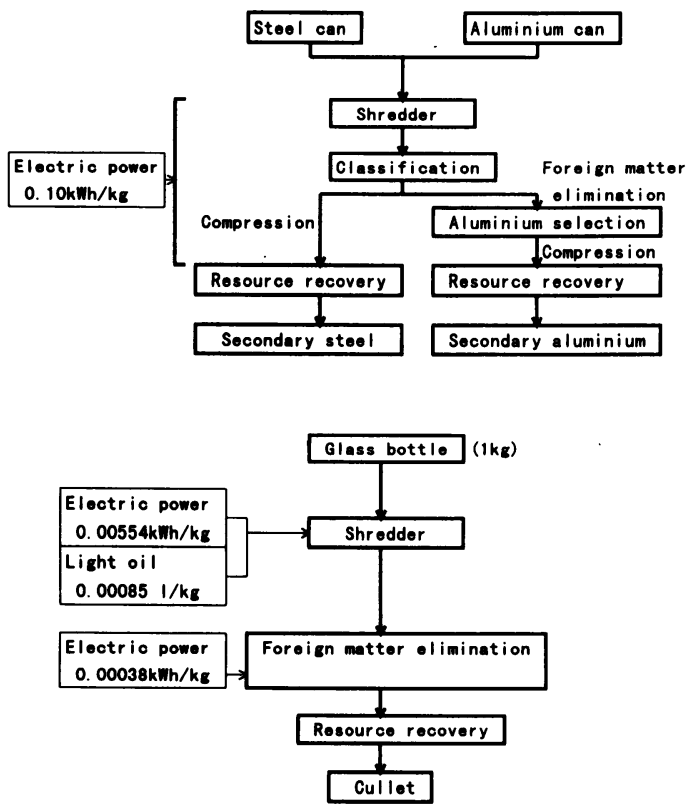

Fig. 3 Re-manufacturing system flow diagram in S-city

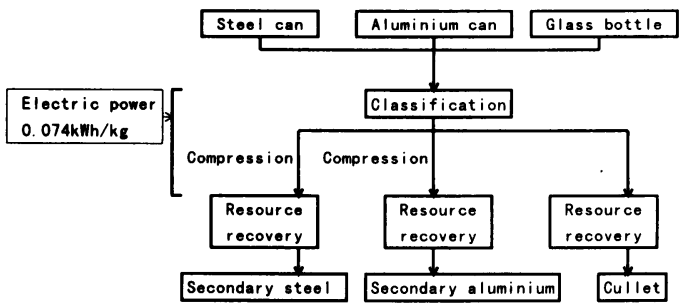

Fig. 4 Re-manufacturing system flow diagram in T-city

である。ここで, 容器の排出量は最近の平均一世帯あた りの年間排出量の調査結果 ${ }^{9)}$ から設定したものである。

再資源化に関する環境負荷原単位は，実地調查した S 市， $\mathrm{T}$ 市の当該施設の実績値を用いた。各方式の再資源 化システムのフローとプロセスでの消費エネルギーを Fig. 3, 4 に示す。

\section{2 インベントリ分析}

3.2.1 評価範囲

2. で述べた SLCA の考え方に基づいて，Fig. 2 で示 した収集 $\rightarrow$ 中間処理・再資源化を範囲とする。

ただし， 2 次製品の材料としての製造するプロセスは 含まない。

\subsection{2 評価対象環境負荷}

本論文では収集・再資源化システムが環境に与える影 響の評価を目的としているため，それらのプロセスで環 境に与える影響と関連が深いエネルギー消費とこれに伴 う大気污染物質排出を評価対象環境負荷項目とする。

なお，再資源化を行うための資本財に関する環境負荷 は考虑しない。

\section{2 .3 大気污染物質排出係数}

エネルギー消費に伴う大気污染物質排出量は, Table 6 に示す大気污染物質排出係数を用いて算出する。電力 については発電時の環境負荷を考える。

\section{3 インパクト評価方法}

3.3.1 インパクトカテゴリー

本論文ではエネルギー消費と関連する Table 7 に示 す 4 つのインパクトカテゴリーについて評価した。なお, 発電時のエネルギ一資源消費は電源構成比（資源エネル ギーデータ集 ${ }^{10)}$ ) に基づいて算出した。

\section{3 .2 環境インパクト指標算出式}

各容器を再資源化するまでの環境インパクトは, 次式

Table 6 Air pollution potential factor with energy consumption

\begin{tabular}{|l|l|l|}
\hline & Electric power & Light oil \\
\hline $\mathrm{CO}_{2}{ }^{*}$ & $0.15 \mathrm{~kg}-\mathrm{C} / \mathrm{kwh}$ & $0.71 \mathrm{~kg}-\mathrm{C} / \ell$ \\
\hline $\mathrm{NOx}^{*}$ & $0.00017 \mathrm{~kg} / \mathrm{kwh}$ & $0.008 \mathrm{~kg} / \boldsymbol{\ell}$ \\
\hline $\mathrm{SOx}^{*}$ & $0.0002 \mathrm{~kg} / \mathrm{kwh}$ & $0.0032 \mathrm{~kg} / \boldsymbol{\ell}$ \\
\hline Heat value $^{* *}$ & $2,250 \mathrm{kcal} / \mathrm{kwh}$ & $9,200 \mathrm{kcal} / \boldsymbol{\ell}$ \\
\hline
\end{tabular}

*（社）プラスチック処理促進協会；プラスチック製品使用量 增加がの地球環境におよぼす影響評価報告書, 1993. 3。

** 総合エネルギー統計。

Table 7 Calculation method of weighting factor

\begin{tabular}{|c|c|c|}
\hline Impact category & $\begin{array}{c}\text { Item of } \\
\text { environmental load }\end{array}$ & Weighting factor \\
\hline $\begin{array}{l}\text { Energy } \\
\text { resources } \\
\text { consumption }\end{array}$ & $\begin{array}{l}\text { Light oil } \\
\text { Electric power }\end{array}$ & $\begin{array}{c}6.9 \times 10^{-11} \\
6.2 \times 10^{-12} \\
\text { (Heat value/ } \\
\text { Proved resources reserve) }\end{array}$ \\
\hline $\begin{array}{l}\text { Greenhouse } \\
\text { effect }\end{array}$ & $\mathrm{CO}_{2}$ & $\begin{array}{c}1.0 \\
\text { (Global warming potential) }\end{array}$ \\
\hline Air pollution & $\begin{array}{l}\text { NOx } \\
\text { SOx }\end{array}$ & $\begin{array}{c}1.00 \\
1.25 \\
(1 \text { /Standard value })\end{array}$ \\
\hline Acidification & $\begin{array}{l}\text { NOx } \\
\text { SOx }\end{array}$ & $\begin{array}{c}0.7 \\
1.0 \\
\text { (Acidification potential) }\end{array}$ \\
\hline
\end{tabular}


によって表される各環境インパクトカテゴリーの環境イ ンパクト指標 $\left(I_{i}\right)$ により求める。

$I_{i}=I_{R i}+I_{T i}$

ここで, $\mathrm{I}_{\mathrm{Ri}}$ ：再資源化の環境インパクト指標値， $\mathrm{I}_{\mathrm{Ti}}$ ：収集 での環境インパクト指標値である。また，変数 $\mathrm{i}$ は環境イ ンパクトカテコリー, 次式以降に示す変数 $\mathrm{j}$ はこのカテゴ リーに関連する環境負荷項目を表す。それぞれの内容は Table 8 に示すとおりである。

なお，評価は一年間の収集・再資源化に対する指標値 で行う。

(1) 再資源化での環境インパクト指標値

再資源化での環境インパクト指標値は次式で表される。

$$
\begin{aligned}
& \mathrm{I}_{\mathrm{Ri}}=\sum_{\mathrm{j}=1}^{\mathrm{n}} \mathrm{C}_{\mathrm{Rij}} \\
& \mathrm{C}_{\mathrm{Rij}}=\mathrm{W}_{\mathrm{ij}} \times \mathrm{L}_{\mathrm{Rj}} \\
& \mathrm{L}_{\mathrm{Rj}}=\sum_{\mathrm{K}=1}^{\mathrm{m}}\left(\mathrm{M}_{\mathrm{K}} \times \mathrm{U}_{\mathrm{K}}\right)
\end{aligned}
$$

ここで, $\mathrm{I}_{\mathrm{Ri}}$ ：再資源化での㻴境インパクト指標値， $\mathrm{C}_{\mathrm{Rij}}$ : 再資源化でのカテゴリー別環境インパクト指標値, $\mathrm{W}_{\mathrm{ij}}$ ： 重み付け係数, $\mathrm{L}_{\mathrm{Rj}}$ : 再資源化での環境負荷, $\mathrm{M}_{\mathrm{K}}$ ：容器の （年間）処理本数, $\mathrm{U}_{\mathrm{K}}$ : 各容器の再資源化時の環境負荷原 単位, $\mathrm{K}$ : 容器を示す変数である。

(2) 収集での環境インパクト指標値

収集の環境インパクト指標値は次式で表される。

$$
\begin{aligned}
& \mathrm{I}_{\mathrm{Ti}}=\sum_{\mathrm{j}=1}^{\mathrm{n}} \mathrm{C}_{\mathrm{Tij}} \\
& \mathrm{C}_{\mathrm{Tij}}=\mathrm{W}_{\mathrm{ij}} \times \mathrm{L}_{\mathrm{Tij}} \\
& \mathrm{L}_{\mathrm{Tij}}=\left(\mathrm{D}_{\mathrm{T}} \div \mathrm{F}\right) \times \mathrm{U}_{\mathrm{p}} \\
& \mathrm{O}=\mathrm{O}_{\mathrm{T}} / \mathrm{H}
\end{aligned}
$$

$\mathrm{V}=\mathrm{O} / \mathrm{S}$

$\mathrm{D}_{\mathrm{T}}=\mathrm{D} \times \mathrm{V} \times \mathrm{H}$

ここで, $\mathrm{I}_{\mathrm{Ti}}$ : 収集での環境インパクト指標値, $\mathrm{C}_{\mathrm{Tij}}$ : 収集 でのカテコリー別環境インパクト指標值, $\mathrm{W}_{\mathrm{ij}}$ : 重み付け

Table 8 Contents of parameter

\begin{tabular}{|c|l|c|l|}
\hline $\mathrm{i}$ & & $\mathrm{j}$ & \\
\hline \multirow{2}{*}{1} & \multirow{2}{*}{$\begin{array}{l}\text { Energy resources } \\
\text { consumption }\end{array}$} & 1 & Light oil \\
\cline { 3 - 4 } & 2 & Electric power \\
\hline 2 & Greenhouse effect & 1 & $\mathrm{CO}_{2}$ \\
\hline \multirow{2}{*}{3} & \multirow{2}{*}{ Air pollution } & 1 & $\mathrm{NOx}$ \\
\cline { 3 - 4 } & & 2 & $\mathrm{SOx}$ \\
\hline \multirow{2}{*}{4} & \multirow{2}{*}{ Acidification } & 1 & $\mathrm{NOx}$ \\
\cline { 3 - 4 } & & 2 & $\mathrm{SOx}$ \\
\hline
\end{tabular}

係数, $\mathrm{L}_{\mathrm{T} i \mathrm{j}}$ ：収集での環境負荷, $\mathrm{D}_{\mathrm{T}}$ : 各容器の年間収集距 離, $\mathrm{F}$ : 燃費, $\mathrm{D}$ : 各容器の平均収集距離, $\mathrm{U}_{\mathrm{p}}$ : 収集時の 環境負荷原単位, $\mathrm{O} ： 1$ 回の収集での収集量, $\mathrm{O}_{\mathrm{T}}$ : 各容器 の (年間) 排出量, $\mathrm{V}: 1$ 回の収集で必要な収集車数（切 り上げ整数) $\mathrm{S}$ : 各容器の積載量, $\mathrm{H}$ ：各容器の年間収集 頻度である。

\section{4 評価結果}

$\mathrm{S}$ 市において 3 種類の容器（スチール缶，アルミ缶， ビン）の収集・再資源化を行う場合に，現行の S 市方 式を， T市方式に変更した場合の環境インパクトを比較 した結果（リサイクルを 1 年間行った場合の合計）を， $\mathrm{S}$ 市方式を 100 として指数化して Fig. 5 〜 8 に示す。

\section{4 .1 環境インパクトの比較}

収集・再資源化の環境インパクトを比較した結果は次 のとおりである。

(1) 3 種類の容器を一括して混合収集し,リサイクル センターで再資源化を行う T市方式の方が S 市方 式と比べてすべてのカテゴリーにおいて環境インパ クトが小さい。

$\mathrm{S}$ 市方式を 100 とすると， T 市方式はエネルギー資 源消費指数では 76 , 温室効果指数では 75 , 大気污 染指数では 77 , 酸性化指数では 77 である。

(2) 両方式とも「再資源化」より「収集」の占める割 合がかなり大きく，S市方式では収集は，エネル ギー資源消費では $78 \%$ ，温室効果では $61 \%$ ，大気 污染では $89 \%$, 酸性化では $89 \%$ を占めている。ま た， T市方式では同じく $81 \% ， 65 \% ， 90 \% ， 91 \%$ を占めている。

(3) 環境インパクトのカテゴリー別では,「ェネル ギー資源消費量」「大気污染」「酸性化」については, 収集プロセスが他のカテゴリーより強い影響を与え, 「温室効果」については逆に収集による影響が弱く なっている。

これは「エネルギー資源消費量」「大気污染」「酸性 化」は NOx, SOx 排出量により評価されるために 収集による軽油消費の影響が強くなり，「温室効果」 のカテコリリーでは $\mathrm{CO}_{2}$ 排出量によって評価される ため, 再資源化での電力消費の影響が強くなるから である。

\subsection{2 プロセス別の比較}

(1) 再資源化

再資源化プロセスのみで S 市方式を 100 として比較 すると, $\mathrm{T}$ 市方式はエネルギー資源消費指数では 65 , 温室効果指数では 67 , 大気污染指数では 59 , 酸性化指 数では 59 である。 
再資源化プロセスで S市方式の方が環境インパクト が大きいのは, このプロセス（スチール缶とアルミ缶の

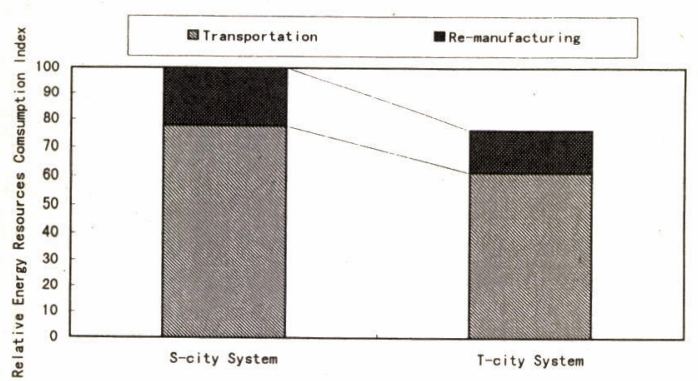

Fig. 5 Relative energy resources consumption index

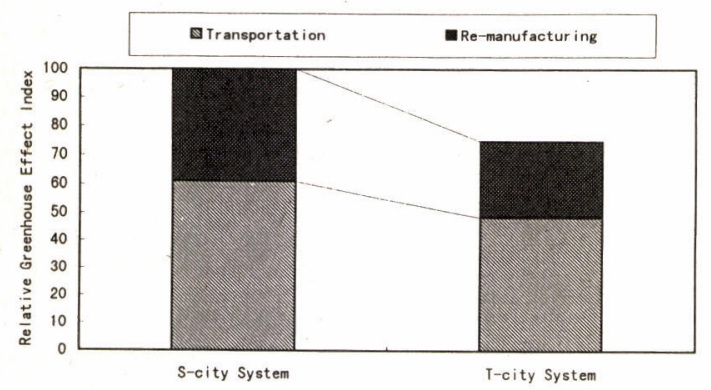

Fig. 6 Relative greenhouse effect index

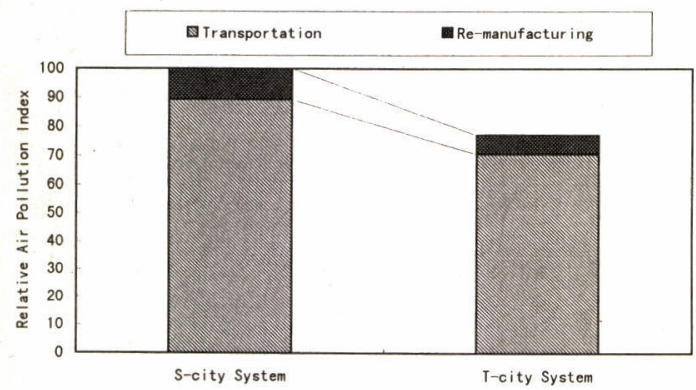

Fig. 7 Relative air pollution index

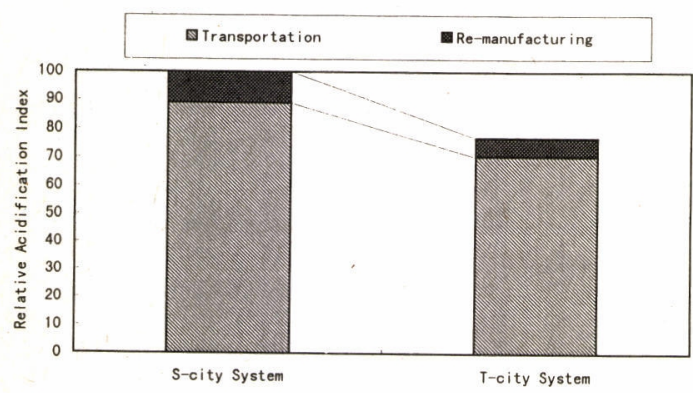

Fig. 8 Relative acidification index
一括破砕 $\rightarrow$ 再資源化）に要するエネルギー消費原単位が， $\mathrm{T}$ 市方式の再資源化によるエネルギー消費原単位より大 きいためである。

\section{(2)収集}

収集プロセスのみで S 市方式を 100 として比較する と, $\mathrm{T}$ 市方式はすべてのカテゴリーでほぼ 80 である。

$\mathrm{S}$ 市方式の方が環境インパクトが大きいのは, S 市方 式ではビンのみを個別に再資源化しており，この再資源 化工場が遠隔地にあること, ビン収集に大型車を使用し ているにもかかわらず T市方式の 3 種容器混載収集之 比べて収集効率が悪いこと, 総収集距離が $\mathrm{T}$ 市方式の 約 1.2 倍になるためである。

\section{5 収集システムの改善による収集・再資源化の環境 インパクト低減化効果}

これまでの結果から，本ケーススタディでは容器類の 収集・再資源化には収集が環境に大きな影響を与え, 特 に現状の S 市方式ではビンの収集による環境への影響 が強いことが明らかになった。このため，S市において ビンのみ遠隔地で再資源化が行われている状況を改善し て, 収集距離を半分 $(114 \mathrm{~km} \rightarrow 57 \mathrm{~km})$ にした場合の 現状との比較, および T市方式との比較を，エネル ギー資源消費量のカテゴリーを例として Fig. 9 に示す。

この結果から， S 市の現状を 100 とすると，収集距離 を半分にすることによって S 市方式ではエネルギー資 源消費の影響は 89 に低減化でき， T 市方式の 76 とそれ ほど大きな差がない結果となった。

また,この収集距離を半分にした場合の S 市方式と $\mathrm{T}$ 市方式の差は, S 市方式の場合, 「スチール缶・アル ミ缶」と「ビン」を別々の収集車で収集するために満杯 にならない状態で行き来する収集車が， T市方式の「ス チール缶・アルミ缶・ビン」を同じ収集車で収集する場 合より多くなることによるあのと考えられる。

この結果は, 収集については分別の方法よりも, 1 種

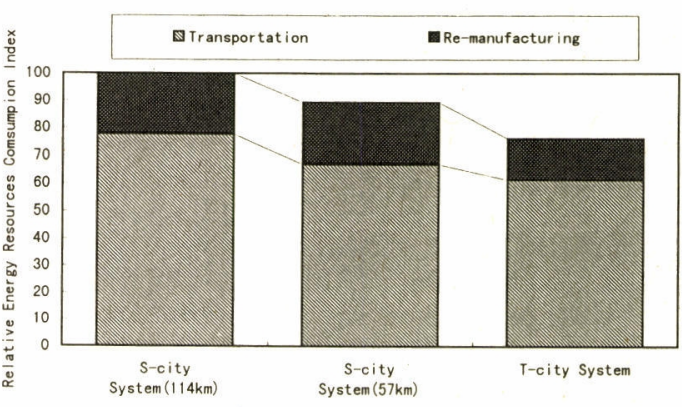

Fig. 9 Relative energy resources consumption index 
のみ離れた施設で再資源化を図っているS市の現状が 環境への影響を大きくする原因となることを示している。

\section{6 評価結果の考察}

$\mathrm{S}$ 市の収集・再資源化システムを対象に行ったケース スタディによる評価結果からは次のようなことがいえる。 ただし，この結果は本ヶーススタディにおける各前提 条件で評価を行った場合に限るものであり, 普遍的なる のではない。

(1) 容器の収集・再資源化では「再資源化」プロセス よりも「収集」プロセスが環境インパクトに強い影 響をおよばす。

(2) 再資源化については，資源別に選別してから再資 源化した方が，一括破砕後に資源別に選別して再資 源化するよりあ環境インパクトが少ない。

(3) 種類の違う容器を別の施設で中間処理・再資源化 するより，1つの施設でまとめて中間処理・再資源 化する方が環境インパクトが少ない。

\section{4. 結論}

本論文ではSLCA を収集・再資源化システムに適用 する考え方について述べ，ケーススタディではある都市 において異なる 2 方式でリサイクルを行った場合の環境 インパクトを比較した。

ケーススタディの評価では, 同じ都市内で同種類, 同 量の容器を再資源化する場合であ収集・再資源化システ ムを変更することにより環境への影響を低減化できる可 能性があることを示した。このことは再資源化にかかる コスト面からの評価ばかりでなく, 可能な (1) 分別方法, (2) 収集頻度, (3) 収集ルート, (4) 再資源化実施工場の位 置の選定, (5) 収集車量の選定, (6) 減容化等の方法を想 定して環境への影響を評価し，できる限り環境への影響 の低減化を図る方法を検討することが重要であることを 示している。

特に，収集距離を環境への影響の低減化を目的として できるだけ少なくなるように見直すことが重要であるこ
とがわかる。

本格的なリサイクルの実施に向けて, SLCA を活用 した環境への影響の少ない収集・再資源化システムを検 討していく必要がある。

\section{[謝 辞]}

本研究の遂行にあたり, 貴重なデータの提供, 調 查にお世話になった方々に心からお礼を申し上げま す。また, データの解析にあたっては, 大学院生原 栄一君の協力を得たことに感謝致します。

\section{考文献}

1) 和田安彦, 三浦浩之, 平田明寿 : Life Cycle Assessment におけるリサイクルフェイスの評価手法に関す る研究, 環境システム研究, Vol. 22, pp. 141-146 (1994)

2）和田安彦, 三浦浩之, 中野加都子：リサイクル可能材 料の使用拡大による環境負荷低減効果，環境システム 研究, Vol. 23, pp. 122-127 (1995)

3）和田安彦, 三浦浩之, 中野加都子：LCA によるリサイ クル効果の定量化一PSPトレイのリサイクルへの適 用一, 土木学会論文集, No. 533/II-34, pp. 237-245 (1996)

4) 和田安彦, 三浦浩之, 中野加都子：LCA によるリサイ クル効果の定量化一自動車バンパヘの適用一, 廃钭物 学会誌, Vol. 7, No. 2, pp. 49-57 (1996)

5) 和田安彦, 三浦浩之, 中野加都子：LCA におけるリサ イクルと廃棄物処理・処分の評価手法とその適用, 土 木学会論文集, No. 539/II-35, pp. 155-165 (1996)

6) 日本における LCA 研究の現状と将来の課題：エコマ テリアル研究会 (1994)

7 ）石川雅紀, LCA からみたリサイクル, 化学工学, Vol. 60, No. 5, pp. 292, (1996)

$8 ）$ ライフサイクルアセスメントの実践一環境負荷低減を 目指して一：化学工業日報社, pp. 21-22, pp. 44-45 (1996)

9 ）環境負荷低減化のために望ましいライフスタイルの研 究：地球環境関西フォーラム (1993)

10）資源エネルギーデータ集 1996 年版：資源エネルギー庁 (1996) 


\title{
Environmental Impact Assessment of Recycling Systems Using the SLCA Method
}

\author{
Kazuko Nakano*, Hiroyuki Miura* and Yasuhiko Wada* \\ * Faculty of Engineering, Kansai University \\ 'Correspondence should be addressed to Yasuhiko Wada : \\ ( 3-3-35 Yamatecho, Suita-city, 564 Japan)
}

\begin{abstract}
In order to reduce the environmental effect of recycling systems, the SLCA method (Service Life Cycle Assessment) was proved to be more effective than PLCA.

In this paper, we outline the SLCAmethod when used with recycling systems and make clarify the differences between the PLCA and SLCA method.

We made a case study in a city by using two recycling systems with the SLCA method.

The results of our study showed that recycling systems (the method of classification, collection frequency, transporting distance) must be assessed from an environmental standpoint.
\end{abstract}

Key words : recycling system, recycling, SLCA, impact assessment, vessels 